\title{
Synthesis and characterization of tungsten trioxide powders prepared from tungstic acids
}

\author{
Helena I.S. Nogueira, Ana M.V. Cavaleiro, João Rocha, \\ Tito Trindade, Júlio D. Pedrosa de Jesus* \\ Department of Chemistry, CICECO, University of Aveiro, Aveiro 3810-193, Portugal
}

Received 16 June 2003; received in revised form 30 October 2003; accepted 25 November 2003

\begin{abstract}
$\mathrm{WO}_{3}$ powders were prepared by the thermal decomposition of tungstic acids $\left(\mathrm{WO}_{3} \cdot n \mathrm{H}_{2} \mathrm{O}, n=1 / 3,1,2\right)$. The tungstic acids were synthesized from $\mathrm{WO}_{4}{ }^{2-}$ aqueous solutions under a variety of conditions of $\mathrm{pH}$, temperature and $\mathrm{W}(\mathrm{VI})$ concentrations. The thermal decomposition of the tungstic acids into $\mathrm{WO}_{3}$ was analysed by $\mathrm{TG}$ and DSC methods. Nano-sized $\mathrm{WO}_{3}$ powders with different morphological characteristics were obtained by thermal treatment of the tungstic acids at $500{ }^{\circ} \mathrm{C}$ in air atmosphere. The morphologies of $\mathrm{WO}_{3}$ powders were characterised by scanning electron microscopy and infrared absorption spectroscopy. Patterns of infrared spectra were related with distinct powder morphologies.
\end{abstract}

(C) 2003 Elsevier Ltd. All rights reserved.

Keywords: A. Oxides; B. Chemical synthesis; C. Fourier transform infrared spectroscopy; C. Scanning electron microscopy

\section{Introduction}

Tungsten trioxide $\left(\mathrm{WO}_{3}\right)$ has been the subject of great interest due to its special electrochromic [1,2], gas sensing [3,4] and catalytic properties [5]. In these applications, the morphological characteristics of the materials like grain size or shape are very important and depend strongly on the preparation method. Therefore, $\mathrm{WO}_{3}$ has been prepared, both in the form of powders and thin films, by a plethora of methods which include chemical vapour deposition [6], sol-gel procedures [7], spray pyrolysis [8], and r.f. magnetron sputtering [9], among other methods.

Tungstic acids are well known compounds with the general formula $\mathrm{WO}_{3} \cdot n \mathrm{H}_{2} \mathrm{O}$. The synthesis of compounds with $n=1 / 3,1 / 2,1$ or 2 has been reported [10-12]. The structure of tungstic acids [10-12] is composed of basic units of $\mathrm{WO}_{6}$ octahedra linked by shared corners, like in tungsten trioxide [12-14]

\footnotetext{
* Corresponding author. Tel.: +351-234-370-735; fax: +351-234-370-084.

E-mail address: jpedrosa@dq.ua.pt (J.D.P. de Jesus).
} 
but in a more open framework. Solution methods involving tungstic acids as precursors have been reported, for example, the preparation of mesoporous $\mathrm{WO}_{3}$ films using as precursor a colloidal solution of tungstic acid [15] and the synthesis of $\mathrm{WO}_{3}$ by treatment of tungstic acid $\left(\mathrm{WO}_{3} \cdot \mathrm{H}_{2} \mathrm{O}\right)$ with organic ligands or water-in-oil emulsions [16]. In this work, $\mathrm{WO}_{3}$ powders were prepared by the thermal decomposition of tungstic acids $\left(\mathrm{WO}_{3} \cdot n \mathrm{H}_{2} \mathrm{O}, n=1 / 3,1\right.$ or 2$)$. These precursors were synthesised under a variety of conditions. The main purpose was to study the influence that the chemical route used to prepare $\mathrm{WO}_{3}$ powders has on its morphological and structural characteristics.

The relation between infrared spectra and the size and shape of particles in microcrystalline powders has been described [17-21]. Powders composed of particles with known size and shape have been characterised by infrared spectroscopy and theoretical spectra were calculated based on the interpretation of surface mode absorptions [17-21]. Good fittings of the theoretical and corresponding experimental spectra were obtained. The lack of consistency among the reported infrared spectra of powdered corundum-type microcrystalline oxides was shown [18] to be due in part to the different particle shape of the samples used. In this paper the relation between morphology and the infrared spectra is explored for tungsten trioxide powders.

\section{Experimental}

\subsection{Syntheses}

Tungstic acids of general formula $\mathrm{WO}_{3} \cdot n \mathrm{H}_{2} \mathrm{O}$ were synthesised using the methods of Freedman [10] (samples 1-7, 9 and 10) and Gerand et al. [11] (sample 8).

\subsection{1. $\mathrm{WO}_{3} \cdot 2 \mathrm{H}_{2} \mathrm{O}$}

2.1.1.1. Samples 1-6. To aqueous solutions of sodium tungstate was added hydrochloric acid $6.0 \mathrm{~mol} \mathrm{dm}^{-3}$ with stirring at room temperature $\left(20^{\circ} \mathrm{C}\right)$. Sodium tungstate dihydrate $(1.0 \mathrm{~g})$ was dissolved in water (from 2 to $20 \mathrm{~cm}^{3}$ ) and different amounts of the $\mathrm{HCl}$ solution (from 4 to $20 \mathrm{~cm}^{3}$ ) were added in order to obtain different concentrations of the initial $\mathrm{W}(\mathrm{VI})$ species and $\mathrm{H}^{+}$(Table 1). Yellow precipitates were formed. The precipitates were filtered, washed several times with water and dried at room temperature.

2.1.1.2. Sample 7. The above procedure was used with hydrochloric acid $0.25 \mathrm{~mol} \mathrm{dm} \mathrm{d}^{-3}\left(500 \mathrm{~cm}^{3}\right)$, that was added to an aqueous solution of sodium tungstate $1.0 \mathrm{~mol} \mathrm{dm}{ }^{-3}\left(10 \mathrm{~cm}^{3}\right)$. The white precipitate obtained was filtered, washed several times with water and dried at room temperature. The white powder obtained was sensitive to sunlight and was kept in the dark.

2.1.1.3. Sample 8. To an aqueous solution of sodium tungstate $0.21 \mathrm{~mol} \mathrm{dm} \mathrm{dm}^{-3}\left(100 \mathrm{~cm}^{3}\right)$ was added hydrochloric acid $1.0 \mathrm{~mol} \mathrm{dm}{ }^{-3}\left(50 \mathrm{~cm}^{3}\right)$ with stirring at $5{ }^{\circ} \mathrm{C}$. Both solutions were previously cooled to $5{ }^{\circ} \mathrm{C}$ and this temperature was maintained for two hours after mixing the solutions. A yellow gel was formed and washed with water by stirring and centrifuging. The gel obtained was dispersed in $4 \mathrm{dm}^{3}$ of water and kept for two months at room temperature. Small yellow crystals were formed in the solution surface together with a yellow powder that settled down. Both solids were filtered and dried at room temperature. 
Table 1

Experimental conditions for the synthesis of tungstic acids (the concentration values refers to initial concentrations of W(VI) species and $\mathrm{H}^{+}$)

\begin{tabular}{lllll}
\hline Sample & Compound & Precipitation conditions & & Temperature $\left({ }^{\circ} \mathrm{C}\right)$ \\
\cline { 3 - 5 } & & {$[\mathrm{W}(\mathrm{VI})]\left(\mathrm{mol} \mathrm{dm}^{-3}\right)$} & {$\left[\mathrm{H}^{+}\right]\left(\mathrm{mol} \mathrm{dm}^{-3}\right)$} & 20 \\
\hline 1 & $\mathrm{WO}_{3} \cdot 2 \mathrm{H}_{2} \mathrm{O}$ pale yellow & 0.10 & 2.0 & 20 \\
2 & $\mathrm{WO}_{3} \cdot 2 \mathrm{H}_{2} \mathrm{O}$ pale yellow & 0.076 & 3.0 & 20 \\
3 & $\mathrm{WO}_{3} \cdot 2 \mathrm{H}_{2} \mathrm{O}$ pale yellow & 0.051 & 4.0 & 20 \\
4 & $\mathrm{WO}_{3} \cdot 2 \mathrm{H}_{2} \mathrm{O}$ pale yellow & 0.10 & 4.0 & 20 \\
5 & $\mathrm{WO}_{3} \cdot 2 \mathrm{H}_{2} \mathrm{O}$ pale yellow & 0.25 & 4.0 & 20 \\
6 & $\mathrm{WO}_{3} \cdot 2 \mathrm{H}_{2} \mathrm{O}$ pale yellow & 0.51 & 4.0 & 20 \\
7 & $\mathrm{WO}_{3} \cdot 2 \mathrm{H}_{2} \mathrm{O}$ colourless & 0.020 & 0.25 & 5 \\
8 & $\mathrm{WO}_{3} \cdot 2 \mathrm{H}_{2} \mathrm{O}$ pale yellow & 0.14 & 0.33 & 100 \\
9 & $\mathrm{WO}_{3} \cdot \mathrm{H}_{2} \mathrm{O}$ dark yellow & 0.10 & 2.7 & 100 \\
\hline 0 & $\mathrm{WO}_{3} \cdot 1 / 3 \mathrm{H}_{2} \mathrm{O}$ colourless & 0.13 & 0.50 &
\end{tabular}

\subsection{2. $\mathrm{WO}_{3} \cdot \mathrm{H}_{2} \mathrm{O}$}

2.1.2.1. Sample 9. To an aqueous solution of sodium tungstate $1.0 \mathrm{~mol} \mathrm{dm}{ }^{-3}\left(25 \mathrm{~cm}^{3}\right)$ was added hydrochloric acid $3.0 \mathrm{~mol} \mathrm{dm}^{-3}\left(225 \mathrm{~cm}^{3}\right)$ with stirring at $100{ }^{\circ} \mathrm{C}$. Both solutions were previously heated to $100{ }^{\circ} \mathrm{C}$ and this temperature was maintained for thirty minutes after mixing the solutions. A dark yellow precipitate was formed. The precipitate was filtered, washed several times with water and dried at $100{ }^{\circ} \mathrm{C}$ for three hours.

\subsection{3. $\mathrm{WO}_{3} \cdot 1 / 3 \mathrm{H}_{2} \mathrm{O}$}

2.1.3.1. Sample 10. To an aqueous solution of sodium tungstate $0.25 \mathrm{~mol} \mathrm{dm}^{-3}\left(100 \mathrm{~cm}^{3}\right)$ was added hydrochloric acid $1.0 \mathrm{~mol} \mathrm{dm}^{-3}\left(100 \mathrm{~cm}^{3}\right)$ with stirring at $100{ }^{\circ} \mathrm{C}$. Both solutions were previously heated to $100{ }^{\circ} \mathrm{C}$ and this temperature was maintained for ten minutes after mixing the solutions. A white precipitate was formed. The precipitate was filtered, washed several times with water and dried at $100{ }^{\circ} \mathrm{C}$ for three hours. The white powder obtained was sensitive to sunlight and was kept in the dark.

\subsection{Preparation of $\mathrm{WO}_{3}$ powders}

Tungsten trioxide was prepared by calcination of the tungstic acids, in air, at $500{ }^{\circ} \mathrm{C}$ over one hour (samples are designated as the respective tungstic acids (1-10) followed by C500).

\subsection{Instrumentation}

The X-ray powder diffraction (XRD) patterns were recorded using a Philips X'Pert instrument operating with $\mathrm{Cu} \mathrm{K} \alpha$ radiation $(\lambda=1.54178 \AA)$ at $40 \mathrm{kV} / 50 \mathrm{~mA}$. A JEOL JSM-35C scanning electron microscope was used to obtain the SEM images. Samples were prepared for microscopy by preparing a suspension of the powders in water, followed by slow evaporation on high-purity aluminium rods. 
Infrared spectra were recorded on a Mattson Polaris FTIR spectrometer using pellets of $2 \mathrm{mg}$ of the sample and $120 \mathrm{mg}$ of spectroscopic-grade $\mathrm{KBr}$. Thermogravimetric analysis was performed using a Mettler TG50 thermobalance and differential scanning calorimetry was measured on a Mettler DSC20 standard cell, both using heating rates of $10{ }^{\circ} \mathrm{C} / \mathrm{min}$. The solid state MAS NMR spectra were recorded using a Bruker MSL 400P spectrometer using TMS as the reference.

\section{Results and discussion}

\subsection{Tungstic acids characterisation}

Tungsten trioxide hydrates (tungstic acids, $\left.\mathrm{WO}_{3} \cdot n \mathrm{H}_{2} \mathrm{O}\right)$ with distinct hydration numbers $(n=1 / 3,1$ or 2) were obtained by changing conditions like temperature and, W(VI) or $\mathrm{H}^{+}$concentrations in a sodium tungstate aqueous solution. These compounds were isolated as crystalline powders (Table 1, samples 1-6 and 8-10) with the exception of an amorphous sample (7). All the crystalline samples were identified by X-ray powder diffraction. Typical SEM images for tungstic acids are shown in Fig. 1.

Tungsten trioxide dihydrates, $\mathrm{WO}_{3} \cdot 2 \mathrm{H}_{2} \mathrm{O}$, were prepared at room temperature using initial concentrations of $\mathrm{H}^{+}$from 0.25 to $4.0 \mathrm{~mol} \mathrm{dm}^{-3}$ (samples 1-8). Though the particle shapes are poorly defined, three different morphological patterns were clearly observed by performing SEM in $\mathrm{WO}_{3} \cdot 2 \mathrm{H}_{2} \mathrm{O}$ particles: nano-sized "round plates" in samples 1-6 (Fig. 1a); agglomerated particles with undefined shape in the amorphous sample 7 (not shown); micrometric rectangular particles in sample 8 (Fig. 1b). In this sample, a longer time of crystallisation was employed resulting in bigger, well-defined particles. Tungsten trioxide monohydrate, $\mathrm{WO}_{3} \cdot \mathrm{H}_{2} \mathrm{O}$, was prepared at $100{ }^{\circ} \mathrm{C}$ using the initial $\mathrm{H}^{+}$ concentration of $2.7 \mathrm{~mol} \mathrm{dm}{ }^{-3}$ (sample 9). The SEM image of $\mathrm{WO}_{3} \cdot \mathrm{H}_{2} \mathrm{O}$ particles (Fig. 1c) shows nano-sized "square plates", with approximately the same size as $\mathrm{WO}_{3} \cdot 2 \mathrm{H}_{2} \mathrm{O}$ particles in samples 1-6 but with a square morphology. The tungsten trioxide hydrate $\mathrm{WO}_{3} \cdot 1 / 3 \mathrm{H}_{2} \mathrm{O}$ was prepared at $100{ }^{\circ} \mathrm{C}$ using the initial $\mathrm{H}^{+}$concentration of $0.50 \mathrm{~mol} \mathrm{dm}{ }^{-3}$ (sample 10). The SEM image of $\mathrm{WO}_{3} \cdot 1 / 3 \mathrm{H}_{2} \mathrm{O}$ (Fig. 1d) shows agglomerates of nano-sized particles, smaller than the $\mathrm{WO}_{3} \cdot 2 \mathrm{H}_{2} \mathrm{O}$ or $\mathrm{WO}_{3} \cdot \mathrm{H}_{2} \mathrm{O}$ particles (considering the nanosized range from 1 to $500 \mathrm{~nm}$ ).

The infrared spectra of the tungstic acids are shown in Fig. 2. The strong absorption in the 500$900 \mathrm{~cm}^{-1}$ region is assigned to the $\mathrm{W}-\mathrm{O}$ vibrations such as in $\mathrm{WO}_{3}$ [22,23]. The bands in the 3100$3550 \mathrm{~cm}^{-1}$ region are assigned to the $\mathrm{O}-\mathrm{H}$ stretching vibrations (asymmetric and symmetric) of coordinated water and the band at $1600 \mathrm{~cm}^{-1}$ is assigned to the $\mathrm{HOH}$ bending of the coordinated water [24]. The $\mathrm{WO}_{3} \cdot 2 \mathrm{H}_{2} \mathrm{O}$ spectrum (Fig. 2a) shows bands at 915,940 and $1005 \mathrm{~cm}^{-1}$. In this region, $\mathrm{WO}_{3} \cdot \mathrm{H}_{2} \mathrm{O}$ (Fig. 2b) absorbs at $945 \mathrm{~cm}^{-1}$ and in the $\mathrm{WO}_{3} \cdot 1 / 3 \mathrm{H}_{2} \mathrm{O}$ spectrum (Fig. 2c) there are no distinct maxima. These bands are possibly due to the vibrations related with coordinated water, possibly with the $\mathrm{W}-\mathrm{OH}_{2}$ bond.

The thermal decomposition of the tungstic acids was monitored using TG and DSC methods (not shown). The $n$ value for each $\mathrm{WO}_{3} \cdot n \mathrm{H}_{2} \mathrm{O}$ sample was calculated from the thermograms. $\mathrm{WO}_{3} \cdot 2 \mathrm{H}_{2} \mathrm{O}$ dehydrates in two separate steps at 85 and $212{ }^{\circ} \mathrm{C}$, respectively, loosing one water molecule at each temperature. $\mathrm{WO}_{3} \cdot \mathrm{H}_{2} \mathrm{O}$ dehydrates at $222{ }^{\circ} \mathrm{C}$, and $\mathrm{WO}_{3} \cdot 1 / 3 \mathrm{H}_{2} \mathrm{O}$ dehydrates gradually in this range of temperatures. The DSC curves show an endothermic peak for each dehydration step at approximately the same temperatures obtained in the thermograms. An exothermic phase transition, at about $460{ }^{\circ} \mathrm{C}$, was observed for the amorphous sample of $\mathrm{WO}_{3} \cdot 2 \mathrm{H}_{2} \mathrm{O}(7)$ and $\mathrm{WO}_{3} \cdot 1 / 3 \mathrm{H}_{2} \mathrm{O}$. 

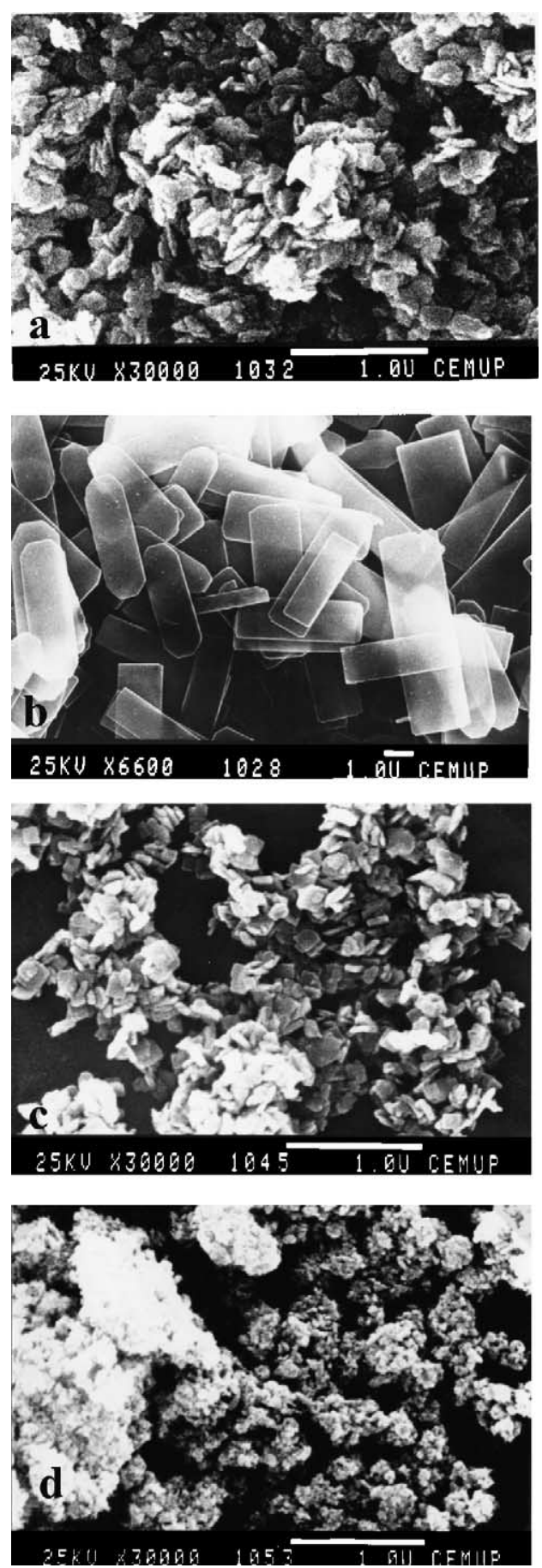

Fig. 1. SEM images of $\mathrm{WO}_{3} \cdot n \mathrm{H}_{2} \mathrm{O}$ particles. $\mathrm{WO}_{3} \cdot 2 \mathrm{H}_{2} \mathrm{O}$ : sample 3 (a) and sample 8 (b); $\mathrm{WO}_{3} \cdot \mathrm{H}_{2} \mathrm{O}$ : sample 9 (c) and WO $3 \cdot 1 /$ $3 \mathrm{H}_{2} \mathrm{O}$ : sample $10(\mathrm{~d})$. 


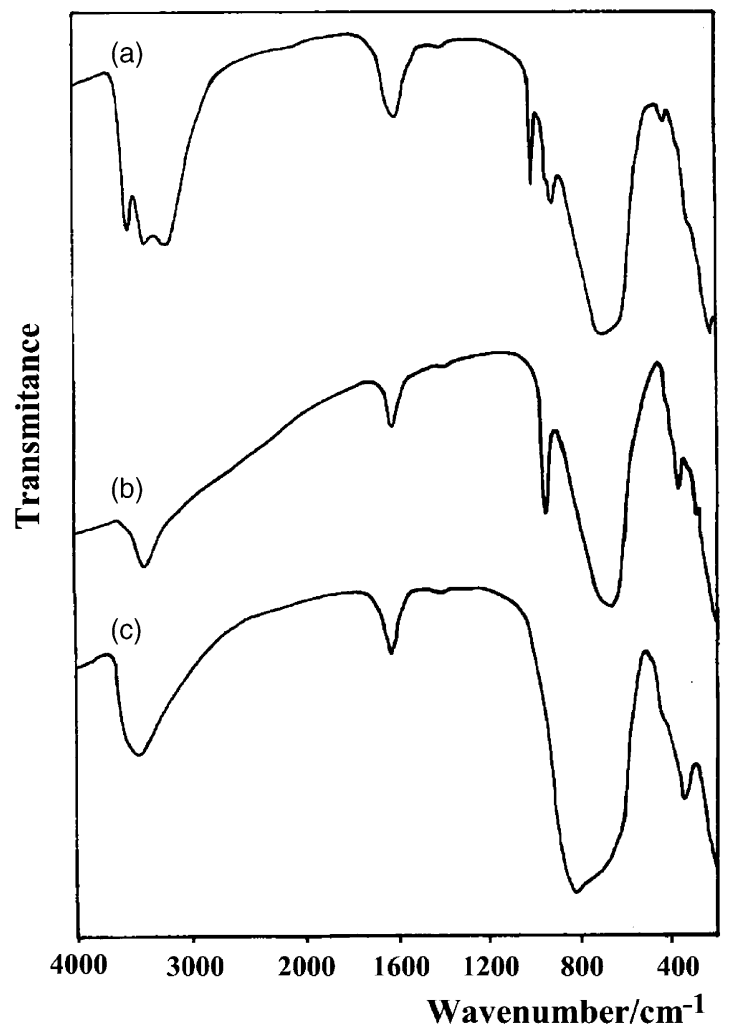

Fig. 2. Infrared spectra of the tungstic acids. $\mathrm{WO}_{3} \cdot 2 \mathrm{H}_{2} \mathrm{O}$ : sample 6 (a); $\mathrm{WO}_{3} \cdot \mathrm{H}_{2} \mathrm{O}$ : sample 9 (b) and $\mathrm{WO}_{3} \cdot 1 / 3 \mathrm{H}_{2} \mathrm{O}$ sample 10 (c).

Expanded high-speed MAS NMR spectra of $\mathrm{WO}_{3} \cdot n \mathrm{H}_{2} \mathrm{O}(n=1 / 3,1,2)$ are shown in Fig. 3. All spectra display two sharp lines at 0.9 and $1.3 \mathrm{ppm}$ with intensities which depend on the sample. These lines have no sidebands associated, even when relatively slow MAS rates $(2-4 \mathrm{kHz})$ are used. This is illustrated in Fig. 4 for the case of $\mathrm{WO}_{3} \cdot \mathrm{H}_{2} \mathrm{O}$. The sidebands observed are all associated with the broad resonance centred at $6.2 \mathrm{ppm}$. The broad peak is assigned to bulk water molecules coordinated to tungsten atoms and the sharp lines to two kinds of mobile surface hydroxyls. Spectral deconvolutions (carried out including the sidebands) show that the contribution of the hydroxyls to the total proton signal is estimated to be less than $5 \%$. Based on variable temperature static ${ }^{1} \mathrm{H}$ data of $\mathrm{WO}_{3} \cdot 1 / 3 \mathrm{H}_{2} \mathrm{O}$, others have previously assigned a Pake doublet to bulk coordinated water molecules and a sharper resonance to surface hydroxyls [25]. The MAS spectrum of $\mathrm{WO}_{3} \cdot 1 / 3 \mathrm{H}_{2} \mathrm{O}$ shown in Fig. $3 \mathrm{c}$ displays two sharp lines at $0.9,1.3 \mathrm{ppm}$ and an ill-resolved shoulder at $2.5 \mathrm{ppm}$ which we assign to three kinds of surface hydroxyls. Together they account for less than $5 \%$ of the total proton signal. The broad line (line width $1114 \mathrm{~Hz}$ ) seen at $5.7 \mathrm{ppm}$ is assigned to bulk water molecules. The resonance at $3.9 \mathrm{ppm}$ is sharper (linewidth $563 \mathrm{~Hz}$ ) than that at $5.7 \mathrm{ppm}$ and it is probably due to adsorbed water. Indeed, its intensity was found to vary slightly from sample to sample. These two resonances have sidebands associated. Together, the hydroxyls and the adsorbed water account for over $30 \%$ of the total proton signal. This is in agreement with our TGA and FTIR data. The spectrum of $\mathrm{WO}_{3} \cdot 2 \mathrm{H}_{2} \mathrm{O}$ (Fig. 3a) displays a broad line and traces of the two sharp peaks at low frequency (together much less than 1\%). 


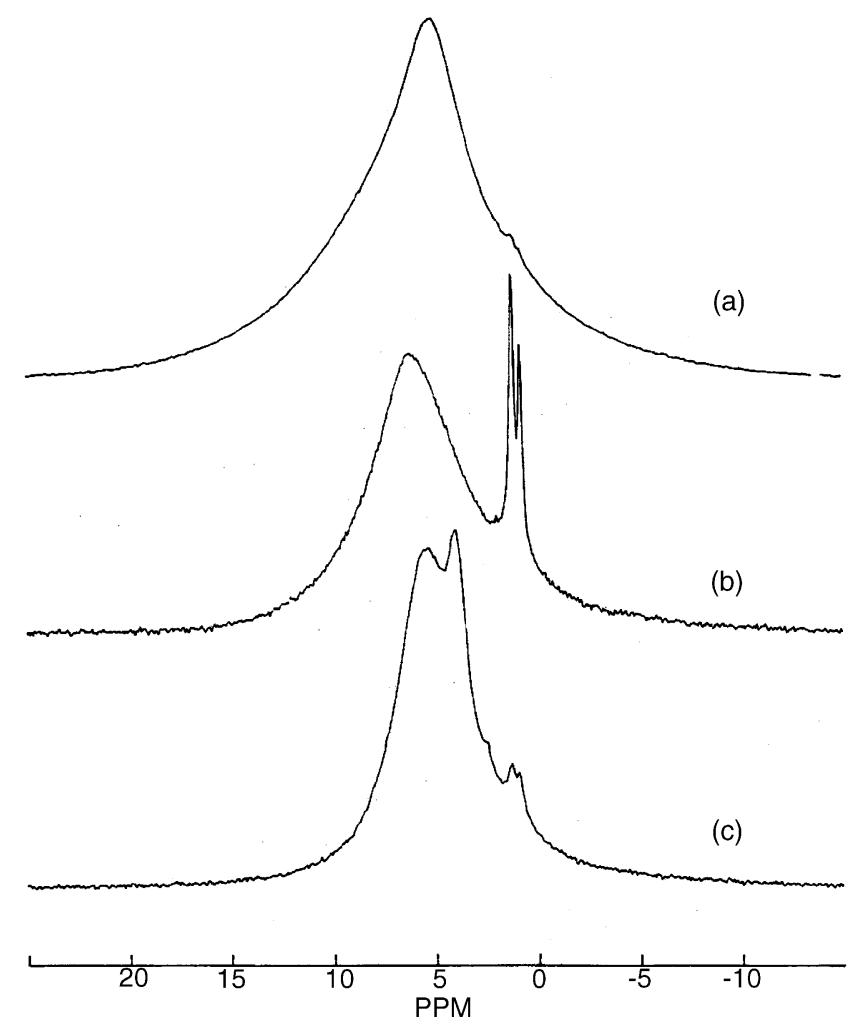

Fig. 3. Expanded high-speed MAS NMR spectra of $\mathrm{WO}_{3} \cdot 2 \mathrm{H}_{2} \mathrm{O}(\mathrm{a}) ; \mathrm{WO}_{3} \cdot \mathrm{H}_{2} \mathrm{O}$ (b) and $\mathrm{WO}_{3} \cdot 1 / 3 \mathrm{H}_{2} \mathrm{O}(\mathrm{c})$.

It is not possible to simulate the broad spectral line with a single peak, two components (at least) centred at ca. 5.2 and $9.4 \mathrm{ppm}$ must be considered. This would support the layered structure previously proposed for $\mathrm{WO}_{3} \cdot 2 \mathrm{H}_{2} \mathrm{O}[26,27]$. There are two kinds of bulk water molecules: those coordinated to the tungsten atoms in the layers and those in the space between the layers which are hydrogen bounded to the layers. We assign the signal at $9.4 \mathrm{ppm}$ to the latter water molecules and the resonance at $5.2 \mathrm{ppm}$ to the coordinated molecules.

\subsection{Use of FTIR/SEM in $\mathrm{WO}_{3}$ powders characterisation}

Tungsten trioxide powders were prepared by calcination of the tungstic acids at $500{ }^{\circ} \mathrm{C}$, in air. $\mathrm{WO}_{3}$ powders with different morphologies were obtained. In general the $\mathrm{WO}_{3}$ powders prepared from $\mathrm{WO}_{3} \cdot 2 \mathrm{H}_{2} \mathrm{O}$ (samples 1C500 to 5C500, 7C500 and 8C500) showed similar morphologies to those of the powders before calcination (Figs. $5 \mathrm{~b}$ and $1 \mathrm{a}$, and Figs. $5 \mathrm{c}$ and $1 \mathrm{~b}$, respectively). The $\mathrm{WO}_{3}$ powder prepared from $\mathrm{WO}_{3} \cdot \mathrm{H}_{2} \mathrm{O}$ (sample 9C500) presents a different morphology from the powder before calcination (Figs. 5a and 1c, respectively) and as shown in Fig. 5a, the $\mathrm{WO}_{3}$ powder obtained is composed of nano-sized ellipsoidal particles. The $\mathrm{WO}_{3}$ powder prepared from $\mathrm{WO}_{3} \cdot 1 / 3 \mathrm{H}_{2} \mathrm{O}$ (sample 10C500) also presents a different morphology from the powder before calcination (Figs. 5d and 1d, respectively); the $\mathrm{WO}_{3}$ powder obtained is very agglomerated and sintering had already started as clearly seen in Fig. 5d. The initial $\mathrm{WO}_{3} \cdot 1 / 3 \mathrm{H}_{2} \mathrm{O}$ powder was composed of nano-sized particles (Fig. 1d), 


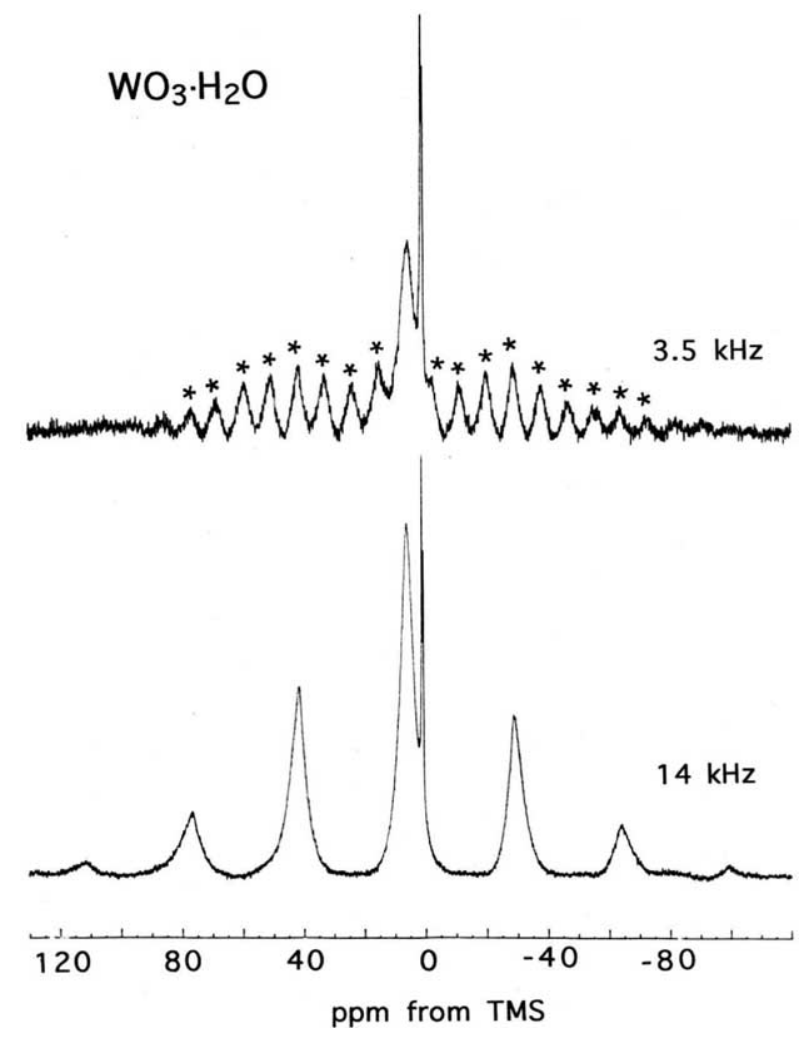

Fig. 4. MAS $(2-4 \mathrm{kHz}) \mathrm{NMR}$ spectrum of $\mathrm{WO}_{3} \cdot \mathrm{H}_{2} \mathrm{O}$.

smaller than those of the other $\mathrm{WO}_{3}$ hydrates, making sintering possible at a temperature as low as $500{ }^{\circ} \mathrm{C}$. The presence of a few hexagonal shaped particles (Fig. 5d) may have its origin in the hexagonal structure of $\mathrm{WO}_{3} \cdot 1 / 3 \mathrm{H}_{2} \mathrm{O}[11]$.

The infrared spectra of the $\mathrm{WO}_{3}$ samples (Fig. 6) show a strong absorption between 600 and $1000 \mathrm{~cm}^{-1}$ associated with the $\mathrm{W}-\mathrm{O}-\mathrm{W}$ stretching modes [22,23]. The weak infrared bands at 1010 and $1035 \mathrm{~cm}^{-1}$ are assigned to the stretching of the $\mathrm{W}=\mathrm{O}$ bonds at the surface [23], and are observed possibly due to the high surface area of these powders. $\mathrm{WO}_{3}$ powders with different morphologies present different profiles of the infrared spectra in the strong absorption region $\left(600-1000 \mathrm{~cm}^{-1}\right)$. Three distinct infrared band profiles can be defined, all presenting a very large absorption band resulting of overlapping of at least three bands, with: (A) maximum intensities at approximately 770 and $850 \mathrm{~cm}^{-1}$ and a shoulder at $930 \mathrm{~cm}^{-1}$, which have very similar intensities (sample 9C500, Fig. 6a); (B) distinct maximum intensities at approximately 740,810 and $960 \mathrm{~cm}^{-1}$, with respectively decreasing intensities (samples 1 C500 to 5C500, Fig. 6b), also with a shoulder at $680 \mathrm{~cm}^{-1}$ that can only clearly be seen in sample 8C500 (Fig. 6c); (C) a shoulder at approximately $630 \mathrm{~cm}^{-1}$ and maximum intensities at 775 and $840 \mathrm{~cm}^{-1}$, with respectively increasing intensities (samples 7C500 and 10C500, Fig. 6d). These IR band profiles $(\mathrm{A}-\mathrm{C})$ can be related with the powders morphologies using the SEM results: (A) nanosized ellipsoidal particles (Fig. 5a); (B) flat particles, round (Fig. 5b) or rectangular shaped (Fig. 5c); (C) agglomerated particles with undefined shape (Fig. 5d). 

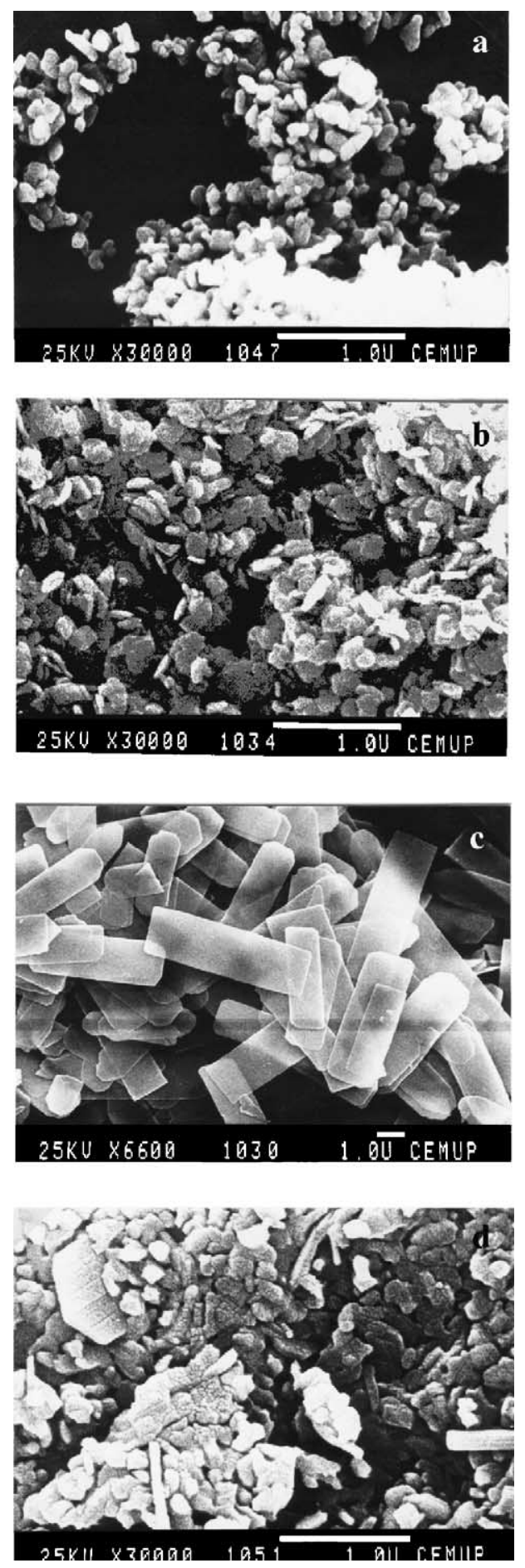

Fig. 5. SEM images of $\mathrm{WO}_{3}$ particles prepared by calcination of the tungstic acids $\mathrm{WO}_{3} \cdot \mathrm{H}_{2} \mathrm{O}$ : sample $9 \mathrm{C} 500(\mathrm{a}), \mathrm{WO}_{3} \cdot 2 \mathrm{H}_{2} \mathrm{O}$ : $3 \mathrm{C} 500$ (b), sample $8 \mathrm{C} 500$ (c); and $\mathrm{WO}_{3} \cdot 1 / 3 \mathrm{H}_{2} \mathrm{O}$ sample $10 \mathrm{C} 500$ (d). 


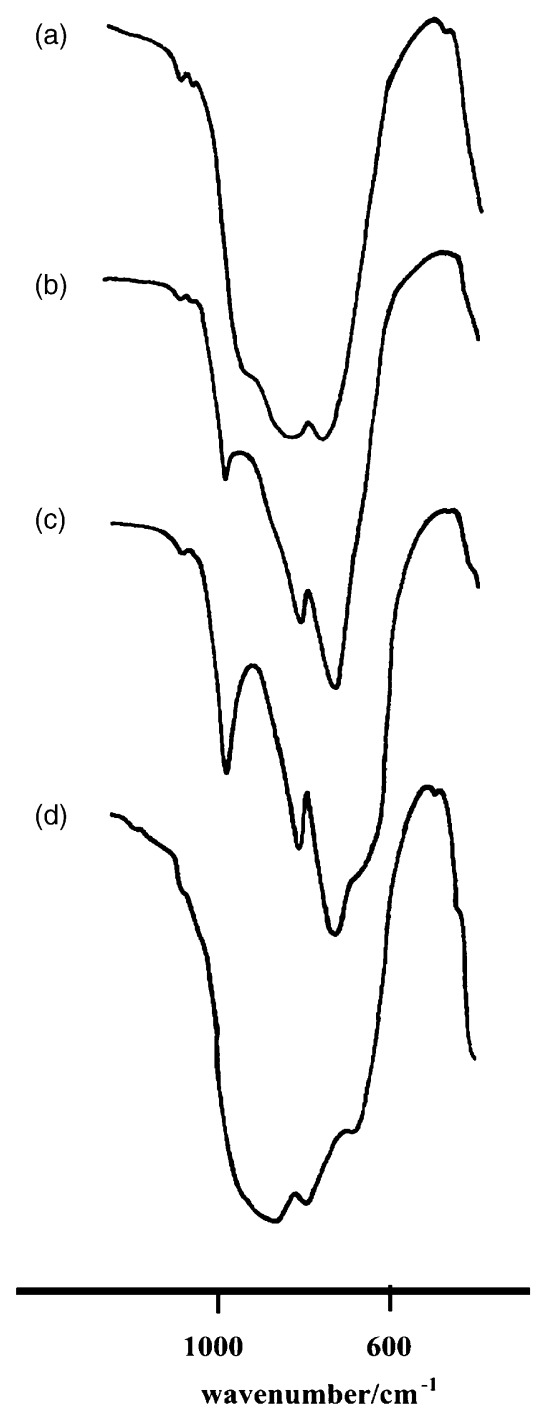

Fig. 6. Infrared spectra of $\mathrm{WO}_{3}$ powders obtained by calcination of the tungstic acids $\mathrm{WO}_{3} \cdot \mathrm{H}_{2} \mathrm{O}$ : sample $9 \mathrm{C} 500$ - IR profile $\mathrm{A}$ (a); $\mathrm{WO}_{3} \cdot 2 \mathrm{H}_{2} \mathrm{O}$ : sample $3 \mathrm{C} 500$ - IR profile $\mathrm{B}$ (b), sample $8 \mathrm{C} 500$-IR profile-B (c) and $\mathrm{WO}_{3} \cdot 1 / 3 \mathrm{H}_{2} \mathrm{O}$ : sample $10 \mathrm{C} 500$ - IR profile $\mathrm{C}(\mathrm{d})$.

\section{Conclusions}

$\mathrm{WO}_{3} \cdot n \mathrm{H}_{2} \mathrm{O}$ powders showing distinct morphological properties were obtained. The particles morphology of $\mathrm{WO}_{3}$ prepared using the $\mathrm{WO}_{3} \cdot n \mathrm{H}_{2} \mathrm{O}$ powders as precursors depends strongly on the precursors morphologies. Changes in the morphological characteristics of the $\mathrm{WO}_{3}$ powders can be anticipated by analysis of the band profiles in the infrared spectra. Due to these features, this technique provides a straightforward method to evaluate in a first approximation the $\mathrm{WO}_{3}$ particles morphology. 


\section{Acknowledgements}

The authors would like to thank the financial support from Fundação para a Ciência e a Tecnologia (FCT, Portugal).

\section{References}

[1] K. Bange, T. Gambke, Adv. Mater. 2 (1990) 10.

[2] S.W.H. Yih, C.T. Wang, Tungsten: Sources, Metallurgy, Properties and Applications, Plenum Press, New York, 1979.

[3] Y.D. Wang, Z.X. Chen, Y.F. Li, Z.L. Zhou, X.H. Wu, Solid State Electron. 45 (2001) 639.

[4] M.D. Antonik, J.E. Schneider, E.L. Wittman, K. Snow, J.F. Vetelino, Thin Solid Films 256 (1995) 247.

[5] H. Hattori, N. Asada, K. Tanabe, Bull. Chem. Soc. Jpn. 51 (1978) 1704.

[6] T. Maruyama, S. Arai, J. Electrochem. Soc. 141 (1994) 1021.

[7] S. Badilescu, P.V. Ashrit, Solid State Ionics 158 (2003) 187.

[8] M. Regragui, M. Addou, A. Outzourhit, J.C. Bernede, E.E. Idrissi, E. Benseddik, A. Kachouane, Thin Solid Films 358 (2000) 40.

[9] L.J. LeGore, R.J. Lad, S.C. Moulzolf, J.V. Vetelino, B.G. Frederik, E.A. Kenik, Thin Solid Films 406 (2002) 79.

[10] M.L. Freedman, J. Am. Chem. Soc. 81 (1959) 3834.

[11] B. Gerand, G. Nowogrocki, J. Guenot, M. Figlarz, J. Solid State Chem. 38 (1981) 312.

[12] R. Nedjar, M.M. Borel, M. Hervieu, B. Raveau, Mater. Res. Bull. 23 (1988) 91.

[13] S. Tanisaki, J. Phys. Soc. Jpn. 15 (1960) 573.

[14] B. Gerand, G. Nowogrocki, J. Guenot, M. Figlarz, J. Solid State Chem. 29 (1979) 429.

[15] C. Santato, M. Odziemkowski, M. Ulmann, J. Augustyinski, J. Am. Chem. Soc. 123 (2001) 10639.

[16] Z.X. Lu, S.M. Kanan, C.P. Tripp, J. Mater. Chem. 12 (2002) 983.

[17] S. Hayashi, N. Nakamori, H. Kanamori, J. Phys. Soc. Jpn. 46 (1979) 176.

[18] C.J. Serna, J.L. Rendon, J.E. Iglesias, Spectrochim. Acta 38A (1982) 797.

[19] C.J. Serna, M. Ocaña, J.E. Iglesias, J. Phys. C: Solid State Phys. 20 (1987) 473.

[20] M. Andrés-Vergés, C.J. Serna, J. Mater. Sci. Lett. (1988) 970.

[21] L. Genzel, T.P. Martin, Surface Sci. 34 (1973) 33.

[22] G. Ramis, C. Cristiani, A.S. Elmi, P. Villa, J. Mol. Catal. 319 (1990) 61.

[23] C.G. Barraclough, J. Stals, Aust. J. Chem. 19 (1966) 741.

[24] K. Nakamoto, Infrared Spectra of Inorganic and Coordination Compounds, Wiley, New York, 1963.

[25] C. Doremieux-Morin, L.C. De Menorval, B. Gerand, J. Solid State Chem. 45 (1982) 193.

[26] V.G. Pitsyuga, L.A. Pozharskaya, M.V. Mokhosoev, E.D. Serdyukova, Russ. J. Inorg. Chem. 25 (1980) 496.

[27] B. Krebs, Acta Crystallogr. B28 (1972) 2222. 